Samaraweera, P.D.P., Perera, B.A.K.S. and Dewagoda, K.G., 2019. Management of payment delays in government funded construction projects in Sri Lanka. In: Sandanayake, Y.G., Gunatilake, S. and Waidyasekara, A. (eds). Proceedings of the $8^{\text {th }}$ World Construction Symposium, Colombo, Sri Lanka, 8-10 November 2019, pp. 411-421. DOI: doi.org/10.31705/WCS.2019.41. Available at: https://2019.ciobwcs.com/papers

\title{
MANAGEMENT OF PAYMENT DELAYS IN GOVERNMENT FUNDED CONSTRUCTION PROJECTS IN SRI LANKA
}

\author{
P.D.P. Samaraweera ${ }^{1}$, B.A.K.S. Perera ${ }^{2}$ and K.G. Dewagoda ${ }^{3}$
}

\begin{abstract}
The successful completion of a construction project will depend on the timeliness of the payments made by the employer, which benefits both the project as well as the parties involved in it. If the payments get delayed, the resulting financial burden will go down the supply chain to reach even the subcontractors and suppliers, thereby further complicating the situation. Since payment delays are common in Sri Lankan construction projects as well, especially when the projects are funded by the government, the proper management of payment delays is important. This research was, therefore, conducted to identify how the consequences of payment delays in government funded projects in Sri Lanka could be properly managed. A literature review and sixteen semi-structured expert interviews were carried out to collect the required data, which were subsequently analysed using manual content analysis. The study identified 77 causes of payment delays in government funded projects and 51 strategies that can minimise them. The study recommends the enactment of the Construction Industry Payment Act, enforcement of regulations that make it mandatory to have a sum of money deposited in an independent escrow account, getting the employers to work only within the stipulated budgets, and getting them to provide payment bonds.
\end{abstract}

Keywords: Causes; Delayed Payments; Government Funded Projects; Strategies.

\section{INTRODUCTION}

Payments are considered as the life blood of construction projects as they often involve very large capital investments (Ameer-Ali, 2006). Francis and Ramachandra (2014) have recognised issues relating to payments as one of the major causes of disputes in the construction industry. Nevertheless, the notion 'early delivery and late payment' has become habitual and routine, specifically in the construction industry (Andalib et al., 2018). It has been reported by Badroldin et al. (2016) that in Malaysia, the government has received many complaints from contractors and service providers about the delays they experience in receiving payments from government agencies. It is the view of most consultants and contractors that delays in making payments by the employers cause projects to suffer (Shaban, 2008). According to Fong (2005), fortunately there are various options available to overcome the delays in making payments in construction projects and some of the developed countries have already made use of some of these options.

\footnotetext{
${ }^{1}$ Airport and Aviation Services Ltd., Sri Lanka, padmalals@gmail.com

2 Department of Building Economics, University of Moratuwa, Sri Lanka, kanchana@uom.lk

${ }^{3}$ Department of Building Economics, University of Moratuwa, Sri Lanka, kaveeshad@uom.lk
} 
Ramachandra et al. (2013) have found that less developed countries require only the minimum level of construction output for their long term and sustainable growth. United Nations (2018) have also stated that in most developing countries, the capital formation in construction accounts for only $7-13 \%$ of the Gross Domestic Product (GDP), whereas in most of the industrialised countries, it accounts for as much as 10-16\% of the GDP.

In Sri Lanka, construction is the fourth largest sector of the national economy and the average contribution of construction to the GDP during the last decade has been around 6.7-8.3\% (Central Bank of Sri Lanka, 2010; 2016). Although according to Francis and Ramachandra (2014), the government has recently implemented a large number of infrastructure development projects in the country, according to Sirimanna (2012), the government owes the consultants and contractors of these projects billions of rupees. The delays in making the payments have even tarnished the image and standard of the construction industry of the country (Francis and Ramachandra, 2014). Francis et al. (2016) have stated that more than $60 \%$ of the main contractors and subcontractors involved in these projects have suffered cash flow problems and that consequently there have been delays in the completion of the projects.

When payments for work done get delayed, it will affect almost all those who have been involved in the work (Artidi and Chotibongs, 2005). Often the financial burden passes down the supply chain to reach the subcontractors and suppliers compounding the situation (El-adaway et al., 2017). This situation could even cause the entire project to fail by making the contractor bankrupt and insolvent (Amoako, 2011) and compelling him to abandon the contract (Nasser, 2013). The result will be simply a waste of public money. Many researchers in the past have explored the issue of delayed payments in the global context. Only a few researchers have, however, studied these issues in relation to government funded projects in Sri Lanka. Therefore, it is important to identify the factors that cause payment delays in government funded construction projects in Sri Lanka and strategies that can manage those payment delays. Accordingly, the aim of this study was to find ways of improving the management of payment delays in government funded construction projects in Sri Lanka by identifying separately the factors causing payment delays by employers, consultants, contractors and others and the strategies that can minimise those payment delays.

\section{LITERATURE REVIEW}

\subsection{PAYMENT DELAYS}

According to Ye and Rahman (2010), payment issues are endemic to construction and have to be recognised explicitly as they tend to recur. Hasmori et al. (2012) have found that payments have always been a major concern of the construction industry and that a majority of the contractors handling government funded projects have experienced payment delays with some experiencing them even in privately funded projects. Hasmori et al. (2012) have also found delayed payments to be common in government funded projects. According to Francis et al. (2016), delayed payments are common in the construction industry of any country, with most of the large-scale government funded projects in Sri Lanka too experiencing such delays. However, according to the National Construction Association of Sri Lanka (2009), the unsatisfactory payment issues experienced by contractors involved in construction projects in Sri Lanka are not specifically dependent on the source of funding of the projects. 
Hussin and Omran (2009) have identified delays in making advance payments as a common issue and Singh (2003) has identified that issues arise when there are delays in issuing interim payment certificates. In many countries, the rapid increase in the delays experienced in closing the final accounts of contractors has adversely affected the good image of the construction industry (Zakaria et al., 2012). Issues related to the closing of final accounts occur during the rationalisation of rates and when the contract administration team fails to rationalise the rates on time (Sambasivan and Soon, 2007).

\subsection{Causes of Payment Delays}

Delayed payments will never bring justice to any party in the construction industry (Artidi and Chotibongs, 2005). Wiguna and Scott (2005) have found that delayed payments cause construction delays and cost overruns. There can be numerous factors responsible for delayed payments (Nazir, 2006). Hughes et al. (1998) believed that delayed payments are basically due to the 'cannot' or 'would not' pay attitude of the employers. Nasser (2013) found that a delayed payment by one party can affect the whole supply chain of payment. This cascade system of payment starts at the financial institution and goes to the main contractor and subcontractor in that order and from the subcontractor moves further down the chain (Ansah, 2011). The insolvency of one party in the payment chain can, therefore, cause severe impacts on parties down the contractual chain (Ansah, 2011).

\subsection{Strategies to Manage Payment Delays}

Several researchers have explored ways of minimising payment issues in various countries. Ramachandra and Rotimi (2011) have identified the strategies used in New Zealand, which included "placing of charging orders and registering caveatable interest on properties, lodging bankruptcy and liquidation proceedings, holding money in trust accounts and getting the sureties to make the payments directly" (p.31). A study conducted in Malaysia has revealed that contractual provisions in the standard forms of a contract, including the right to regular periodic payments, right to a defined time frame for payments and right to a speedy dispute resolution mechanism could minimise payment issues to a certain extent (Danuri et al., 2012). Francis et al. (2016) have found that in Sri Lanka, contractors tend to use contractual provisions while subcontractors tend to adopt various other strategies. The authors further recommend obtaining a security from the employer through a bank in the form of a 'payment bond' and to use a schedule of payments as a part of the contract to ensure regular payments to contractors.

\subsection{IMPORTANCE OF MANAgING PAYMENT DELAYS IN GOVERNMENT FUNDED CONSTRUCTION PROJECTS}

The National Construction Association of Sri Lanka (2009) has reported that there are many foreign contractors who are keen on investing in property development projects in Sri Lanka, which could benefit the economy of the country. These foreign contractors can afford such investments as they can obtain financial support from the government through low interest loans. However, any payment delays they encounter can adversely affect their growth and development. Moreover, these contractors are obliged to take care of their employees by providing them with on the job training or in-house training, recreation facilities, welfare facilities, work safety, job security and job satisfaction to ensure the quality and speed of construction. Thus, the management of payment delays in government funded projects in Sri Lanka is critical. 


\section{RESEARCH METHODOLOGY}

Given the benefits and flexibility of the qualitative approach, this research used the qualitative approach to evaluate the management of payment delays in government funded construction projects using expert interviews. Interviews are considered as the best option for data collection as they help to obtain the opinions of the interviewees in detail (Punch, 2014). Fellows and Liu (2015) also believed that expert interviews are best suited to collect data using the experience of the interviewees. This study used 16 semi structured face-to-face interviews. Each interview lasted for 45 to 60 minutes. The interviewees were selected using purposive sampling, based on their exposure to issues related to delayed payments in government funded building construction projects in Sri Lanka. Out of the 16 interviewees selected, 10 were from the quantity surveying field while the rest were from the civil engineering field. The sample represented client, consultant and contractor organisations. All of the interviewees had more than 15 years of experience in large scale building construction and project management in the state sector. Using the literature review findings, a list of general causes of delayed payments and the strategies that can be used to overcome them was prepared and the interview guideline was prepared based on that list to achieve the research objectives. The data collected were analysed manually using content analysis. Content analysis is a technique for making replicable and valid inferences from texts (or other meaningful matter) to the contexts of their use (White and Marsh, 2006).

\section{RESEARCH FINDINGS}

\subsection{Causes of Payment Delays}

One of the major objectives of the study was to identify the factors that delay the payments made by parties involved in government construction projects in Sri Lanka. For this, information that was gathered from the literature was validated through the expert interviews. The interviewees had to go through the literature review findings and identify specifically the causes of delayed payments in the government funded projects in Sri Lanka. Table 1 presents the most significant causes of these delayed payments.

Table 1: Factors causing delayed payments in the construction projects in Sri Lanka

\begin{tabular}{|c|c|c|c|}
\hline Employer & Consultant & Contractor & Others \\
\hline $\begin{array}{l}\text { Involvement of too } \\
\text { many parties in payment } \\
\text { certification }\end{array}$ & $\begin{array}{l}\text { Delay in certifying the } \\
\text { payment application }\end{array}$ & $\begin{array}{l}\text { Insufficient } \\
\text { documentation and } \\
\text { information provided } \\
\text { for the valuation }\end{array}$ & $\begin{array}{l}\text { Instability of the } \\
\text { financial market }\end{array}$ \\
\hline $\begin{array}{l}\text { Further evaluation of the } \\
\text { payment applications } \\
\text { made by the contractor }\end{array}$ & $\begin{array}{l}\text { Slow processing of the } \\
\text { variation orders }\end{array}$ & $\begin{array}{l}\text { Poor communication } \\
\text { among the parties }\end{array}$ & $\begin{array}{l}\text { Frequent changes in } \\
\text { the exchange rates }\end{array}$ \\
\hline $\begin{array}{l}\text { Poor financial and } \\
\text { business management }\end{array}$ & $\begin{array}{l}\text { Heavy workload } \\
\text { involved in evaluating } \\
\text { the work done }\end{array}$ & $\begin{array}{l}\text { Mistakes found in the } \\
\text { claims }\end{array}$ & $\begin{array}{l}\text { Political/Policy } \\
\text { changes }\end{array}$ \\
\hline $\begin{array}{l}\text { Delays in payment } \\
\text { certification }\end{array}$ & $\begin{array}{l}\text { Frequent design } \\
\text { changes }\end{array}$ & $\begin{array}{l}\text { Cost overruns and } \\
\text { contract failures }\end{array}$ & $\begin{array}{l}\text { Local payment } \\
\text { culture/attitude }\end{array}$ \\
\hline $\begin{array}{l}\text { Failure to agree on the } \\
\text { valuation of work }\end{array}$ & $\begin{array}{l}\text { Disputes over the } \\
\text { quality of the work }\end{array}$ & $\begin{array}{l}\text { Delay in submitting } \\
\text { claims }\end{array}$ & Political involvements \\
\hline
\end{tabular}




\begin{tabular}{|c|c|c|c|}
\hline Employer & Consultant & Contractor & Others \\
\hline $\begin{array}{l}\text { Government } \\
\text { bureaucracy }\end{array}$ & $\begin{array}{l}\text { Not having meetings } \\
\text { frequently to address } \\
\text { work problems }\end{array}$ & $\begin{array}{l}\text { Failure to agree on the } \\
\text { valuation of work }\end{array}$ & $\begin{array}{l}\text { Highly competitive } \\
\text { market conditions }\end{array}$ \\
\hline $\begin{array}{l}\text { Withholding of the } \\
\text { payments }\end{array}$ & $\begin{array}{l}\text { Internal } \\
\text { conflicts/disputes }\end{array}$ & $\begin{array}{l}\text { Low labour } \\
\text { productivity }\end{array}$ & $\begin{array}{l}\text { Legislative procedures } \\
\text { (Construction } \\
\text { Contracts Act) }\end{array}$ \\
\hline $\begin{array}{l}\text { Lengthy procedures that } \\
\text { delay the granting of } \\
\text { approvals by the internal } \\
\text { departments }\end{array}$ & $\begin{array}{l}\text { Misinterpretation of } \\
\text { the employer's } \\
\text { requirement for } \\
\text { variation orders }\end{array}$ & $\begin{array}{l}\text { Improper supervision } \\
\text { and financial control }\end{array}$ & $\begin{array}{l}\text { Delay in obtaining } \\
\text { approvals from } \\
\text { external authorities }\end{array}$ \\
\hline $\begin{array}{l}\text { Budgetary allocations } \\
\text { made by the treasury }\end{array}$ & $\begin{array}{l}\text { Disputes over payment } \\
\text { claims and responses }\end{array}$ & $\begin{array}{l}\text { Failure to follow } \\
\text { contractual procedures }\end{array}$ & $\begin{array}{l}\text { Lack of resources like } \\
\text { labour, materials etc. }\end{array}$ \\
\hline $\begin{array}{l}\text { Underpayment or non- } \\
\text { payment of certified } \\
\text { payments }\end{array}$ & Underpaid claims & $\begin{array}{l}\text { Main contractor's } \\
\text { failure to pay } \\
\text { subcontractors }\end{array}$ & \\
\hline $\begin{array}{l}\text { Contract is too } \\
\text { complicated to be } \\
\text { understood by the two } \\
\text { parties }\end{array}$ & $\begin{array}{l}\text { Standard of the } \\
\text { quantity surveyor } \\
\text { management system }\end{array}$ & $\begin{array}{l}\text { Improper payment } \\
\text { applications }\end{array}$ & \\
\hline $\begin{array}{l}\text { Assumption that the } \\
\text { contractor would } \\
\text { finance the project in } \\
\text { advance in the event of } \\
\text { delayed payments }\end{array}$ & $\begin{array}{l}\text { Poor technical and } \\
\text { managerial skills of } \\
\text { the staff }\end{array}$ & $\begin{array}{l}\text { Capital lock up/ Cash } \\
\text { flow difficulties due to } \\
\text { lack of initial capital }\end{array}$ & \\
\hline $\begin{array}{l}\text { Long internal auditing } \\
\text { procedures }\end{array}$ & $\begin{array}{l}\text { Inaccurate bills of } \\
\text { quantities }\end{array}$ & $\begin{array}{l}\text { Poor quality of the } \\
\text { work }\end{array}$ & \\
\hline $\begin{array}{l}\text { Contract being not } \\
\text { sufficiently } \\
\text { comprehensive with } \\
\text { regard to payments }\end{array}$ & $\begin{array}{l}\text { Inaccurate } \\
\text { preliminary/ } \\
\text { engineer's estimate }\end{array}$ & $\begin{array}{l}\text { Delaying of the } \\
\text { payments to the } \\
\text { subcontractors until } \\
\text { the receipt of the } \\
\text { interim payment } \\
\text { certificate }\end{array}$ & \\
\hline $\begin{array}{l}\text { Liquidated damages } \\
\text { claimed by the employer }\end{array}$ & $\begin{array}{l}\text { Lack of a proper } \\
\text { quantity surveying } \\
\text { management system }\end{array}$ & Invalid claims & \\
\hline Procurement system & $\begin{array}{l}\text { Poor coordination } \\
\text { between the engineer } \\
\text { and employer }\end{array}$ & $\begin{array}{l}\text { Lack of knowledge } \\
\text { and experience in the } \\
\text { field }\end{array}$ & \\
\hline $\begin{array}{l}\text { Hidden agenda that } \\
\text { facilitates malpractices }\end{array}$ & $\begin{array}{l}\text { Malpractices of the } \\
\text { engineer }\end{array}$ & $\begin{array}{l}\text { Acceptance of } \\
\text { generous payment } \\
\text { terms offered by the } \\
\text { employer to win the } \\
\text { tender }\end{array}$ & \\
\hline $\begin{array}{l}\text { Delay in issuing the } \\
\text { taking over certificate }\end{array}$ & $\begin{array}{l}\text { Certification of the } \% \\
\text { payment being not } \\
\text { proportionate to the } \\
\text { actual work done }\end{array}$ & $\begin{array}{l}\text { Nomination of } \\
\text { subcontractors without } \\
\text { considering the quality } \\
\text { of their work / past } \\
\text { experience }\end{array}$ & \\
\hline
\end{tabular}




\begin{tabular}{l|l|l|l}
\hline \multicolumn{1}{c}{ Employer } & \multicolumn{1}{c}{ Consultant } & \multicolumn{1}{c}{ Contractor } & Others \\
\hline $\begin{array}{l}\text { Dragging the payment } \\
\text { even after its } \\
\text { certification }\end{array}$ & $\begin{array}{l}\text { Disregard of the } \\
\text { Liability Act }\end{array}$ & $\begin{array}{l}\text { Failure to understand } \\
\text { the contract agreement }\end{array}$ & \\
\hline $\begin{array}{l}\text { Misleading payment } \\
\text { procedure due to privity } \\
\text { of contract }\end{array}$ & $\begin{array}{l}\text { Inaccurate/erroneous } \\
\text { tender document }\end{array}$ & $\begin{array}{l}\text { Lack of qualified staff } \\
\text { at the site }\end{array}$ & \\
\hline $\begin{array}{l}\text { Employer 's } \\
\text { representatives } \\
\text { disregarding the }\end{array}$ & $\begin{array}{l}\text { Delay in submitting } \\
\text { interim payment } \\
\text { applications }\end{array}$ & \\
$\begin{array}{l}\text { Liability Act } \\
\text { Failure to return the } \\
\text { retention }\end{array}$ & $\begin{array}{l}\text { Misinterpretation of } \\
\text { the employer's } \\
\text { requirement for } \\
\text { variation orders }\end{array}$ & \\
\hline $\begin{array}{l}\text { Lack of decision making } \\
\text { capabilities }\end{array}$ & & \\
\hline $\begin{array}{l}\text { Payments for variations } \\
\text { and extra works made } \\
\text { only with the final } \\
\text { payment }\end{array}$ & & \\
\hline
\end{tabular}

Introduced at the Expert Interviews

The highlighted factors were identified by the expert interviewees as being of particular relevance to Sri Lanka. Among the factors caused by the employer, budgetary provisions made by the treasury was recognised as a critical factor. In this regard, Francis and Ramachandra (2014) have disclosed that the government does not have adequate funds in the treasury to make the payments and that an extensive procedure has to be followed when making payments. According to the literature and the majority of the interviewees, the most critical factor that causes payment delays is the delay on the part of the consultant in certifying the payment applications. Ramachandra and Rotimi (2015) have highlighted that consultants often make discretionary deductions from the payments due to contractors, withhold their payments unreasonably or delay the issuance of their payment certificates. On the other hand, the two most common causes of payment delays for which the contractors are responsible are the insufficient documentation and information provided for valuation and the submission of erroneous claims. Although most of the past studies have attributed payment delays to the local payment culture/attitude, only nine of the interviewees were in agreement with it. Pettigrew (2005) highlighted that the industry has a 'work first, and get paid later' attitude, which worsens the situation. Furthermore, some of the factors causing payment delays, such as the delaying of the payment certification; failure to agree to the valuation of work; poor coordination among parties; failure to follow contractual procedures related to payments; and lack of an efficient quantity surveying management system were factors common to all the parties involved with all of them having a significant influence on the payment delays.

\subsection{Strategies that Can be Adopted to Manage Payment Delays}

In order to identify the strategies that can be adopted by employers, consultants and contractors to minimise payment delays in government funded construction projects, the strategies adopted in other countries were identified from the literature and the expert 
interviews were used to ascertain their relevance to government funded projects in Sri Lanka. Table 2 below presents these strategies.

Table 2: Strategies suitable for managing delayed payments

\begin{tabular}{|c|c|c|c|}
\hline Employer & Consultant & Contractor & Others \\
\hline $\begin{array}{l}\text { Working within the } \\
\text { stipulated budget }\end{array}$ & $\begin{array}{l}\text { Setting a defined time } \\
\text { frame for payments }\end{array}$ & $\begin{array}{l}\text { Submitting timely and } \\
\text { accurate invoices } \\
\text { complete with all } \\
\text { required } \\
\text { documentation }\end{array}$ & $\begin{array}{l}\text { Action taken by } \\
\text { professional bodies } \\
\text { and government } \\
\text { agencies }\end{array}$ \\
\hline $\begin{array}{l}\text { Understanding and } \\
\text { studying the payment } \\
\text { requirements of the } \\
\text { project }\end{array}$ & $\begin{array}{l}\text { Initiating a speedy } \\
\text { dispute resolution } \\
\text { mechanism }\end{array}$ & $\begin{array}{l}\text { Negotiating payment } \\
\text { terms with the } \\
\text { consultant to ensure a } \\
\text { healthy cash flow }\end{array}$ & $\begin{array}{l}\text { Introducing payment- } \\
\text { related legislation }\end{array}$ \\
\hline $\begin{array}{l}\text { Negotiating payment } \\
\text { terms with the } \\
\text { contractor to ensure a } \\
\text { healthy cash flow }\end{array}$ & $\begin{array}{l}\text { Removing the "Pay } \\
\text { when Paid" Clause in } \\
\text { the contract }\end{array}$ & $\begin{array}{l}\text { Using an on account } \\
\text { payment }\end{array}$ & $\begin{array}{l}\text { Giving publicity to the } \\
\text { poor payment } \\
\text { practices of the } \\
\text { employers }\end{array}$ \\
\hline $\begin{array}{l}\text { Using an on account } \\
\text { payment }\end{array}$ & $\begin{array}{l}\text { Getting periodic } \\
\text { budgetary allocations } \\
\text { from the employer }\end{array}$ & $\begin{array}{l}\text { Obtaining a right to } \\
\text { slow down work until } \\
\text { the payment is } \\
\text { received }\end{array}$ & $\begin{array}{l}\text { Introducing standard } \\
\text { bidding documents for } \\
\text { the main contractors } \\
\text { and subcontractors }\end{array}$ \\
\hline $\begin{array}{l}\text { Taking appropriate } \\
\text { security measures in } \\
\text { the form of a payment } \\
\text { bond }\end{array}$ & $\begin{array}{l}\text { Sticking to the } \\
\text { Conditions of Contract } \\
\text { and issuing drawings, } \\
\text { approvals, } \\
\text { instructions, etc., on } \\
\text { time }\end{array}$ & $\begin{array}{l}\text { Creating a mandatory } \\
\text { trust account or } \\
\text { keeping retention } \\
\text { money }\end{array}$ & $\begin{array}{l}\text { Amending the possible } \\
\text { disputes related to } \\
\text { Methods of } \\
\text { Measurements }\end{array}$ \\
\hline $\begin{array}{l}\text { Requiring the owner } \\
\text { to provide a payment } \\
\text { guarantee or bond }\end{array}$ & $\begin{array}{l}\text { Being punctual and } \\
\text { impartial to the } \\
\text { employer }\end{array}$ & $\begin{array}{l}\text { Setting a defined time } \\
\text { frame for payments }\end{array}$ & \\
\hline $\begin{array}{l}\text { Eliminating } \\
\text { bureaucracy }\end{array}$ & $\begin{array}{l}\text { Allowing flexibility } \\
\text { for the minimum } \\
\text { payment when } \\
\text { payments get delayed }\end{array}$ & $\begin{array}{l}\text { Requesting a right to } \\
\text { suspend the work until } \\
\text { the payment is } \\
\text { received }\end{array}$ & \\
\hline $\begin{array}{l}\text { Having an appropriate } \\
\text { budgetary allocation } \\
\text { updated with } \\
\text { variations }\end{array}$ & $\begin{array}{l}\text { Defining the level of } \\
\text { work done }\end{array}$ & $\begin{array}{l}\text { Charging interest on } \\
\text { the delayed payments }\end{array}$ & \\
\hline $\begin{array}{l}\text { Getting the internal } \\
\text { audit unit to have a } \\
\text { better understanding } \\
\text { of the payment terms }\end{array}$ & $\begin{array}{l}\text { Allowing flexibility } \\
\text { for recovering the } \\
\text { advance payment } \\
\text { when payments get } \\
\text { delayed }\end{array}$ & $\begin{array}{l}\text { Applying for a term } \\
\text { loan from a bank to } \\
\text { cover the } \\
\text { consequences of late } \\
\text { payments }\end{array}$ & \\
\hline $\begin{array}{l}\text { Having an advisory } \\
\text { team for major } \\
\text { contracts }\end{array}$ & $\begin{array}{l}\text { Getting an overdraft } \\
\text { facility }\end{array}$ & $\begin{array}{l}\text { Removing the "Pay } \\
\text { when Paid" Clause } \\
\text { from the contract }\end{array}$ & \\
\hline $\begin{array}{l}\text { Getting the approvals } \\
\text { of the relevant } \\
\text { authorities at the }\end{array}$ & & $\begin{array}{l}\text { Sending a letter of } \\
\text { notice through the } \\
\text { lawyer }\end{array}$ & \\
\hline
\end{tabular}




\begin{tabular}{|c|c|c|c|}
\hline Employer & Consultant & Contractor & Others \\
\hline \multicolumn{4}{|l|}{$\begin{array}{l}\text { initial stage of the } \\
\text { project itself (e.g.: } \\
\text { EIA, TIA etc.) }\end{array}$} \\
\hline $\begin{array}{l}\text { Trying to keep the } \\
\text { work unchanged or } \\
\text { minimizing variations }\end{array}$ & & $\begin{array}{l}\text { Chasing the payment } \\
\text { relentlessly }\end{array}$ & \\
\hline $\begin{array}{l}\text { Requesting a credit } \\
\text { facility from the } \\
\text { contractor in the name } \\
\text { of the contract }\end{array}$ & & $\begin{array}{l}\text { Transferring funds } \\
\text { from other projects }\end{array}$ & \\
\hline $\begin{array}{l}\text { Using stage } \\
\text { payments to simplify } \\
\text { payment procedures }\end{array}$ & & $\begin{array}{l}\text { Opening an escrow } \\
\text { account for the } \\
\text { project, particularly } \\
\text { for transactions } \\
\text { between the employer } \\
\text { and the contractor }\end{array}$ & \\
\hline $\begin{array}{l}\text { Releasing a part } \\
\text { payment for the } \\
\text { interim payment } \\
\text { application when the } \\
\text { payment is delayed }\end{array}$ & & $\begin{array}{l}\text { Releasing pending } \\
\text { payments by getting a } \\
\text { bond from the } \\
\text { contractor }\end{array}$ & \\
\hline $\begin{array}{l}\text { Granting an additional } \\
\text { advance payment } \\
\text { when needed }\end{array}$ & & $\begin{array}{l}\text { Including a provision } \\
\text { in the contract to refer } \\
\text { to the financial status } \\
\text { of the employer }\end{array}$ & \\
\hline \multirow{3}{*}{$\begin{array}{l}\text { Minimizing the } \\
\text { amount of provisional } \\
\text { sum stated in the } \\
\text { contract }\end{array}$} & & $\begin{array}{l}\text { Increasing the interest } \\
\text { rate for late payments }\end{array}$ & \\
\hline & & $\begin{array}{l}\text { Monitoring the cash } \\
\text { flow of the } \\
\text { subcontractors }\end{array}$ & \\
\hline & & $\begin{array}{l}\text { Giving timely } \\
\text { notification to the } \\
\text { engineer about the } \\
\text { additional works } \\
\text { required and the lack } \\
\text { of details of same }\end{array}$ & \\
\hline
\end{tabular}

Introduced at the Expert Interviews

The strategies that are highlighted were proposed by the expert interviewees and the others were those identified from the literature and accepted by the interviewees. The interviewees emphasised the need to provide a payment guarantee or bond similar to what was proposed by Fong (2005), to ensure payments even when there is a default by a paying party. This payment guarantee can be even in the form of a promissory note which is a promise a client makes to the relevant party to pay a specific amount of money upon request or at a specified future date. Several strategies, such as "negotiating payment terms to ensure a healthy cash flow"; "use of an on account payment" and "defining a time frame for payment" were found to be common to all the parties. Amoako (2011) 
proposed the setting up of a defined time frame for payment as a strategy that can eliminate payment delays. The time frame can be defined under certain conditions based on previous experience. According to Ameer-Ali (2006), many sub-contracts or sub-sub contracts contain "pay when paid" or "pay if paid" clauses. However, according to most of the interviewees, "pay when paid" or "back to back" payment clauses are not contractual and are unofficially used by main contractors and sub-contractors to withhold payments. The interviewees suggested to remove this "pay when paid" clause from the contract being the third most important strategy that will help a client to manage payment delays. They were also of the view that the strategies "right to slow down the work until payment is received", "right to suspend the work until payment is received" and "charging interest on late payments" mentioned in the literature are general contract provisions which have to be followed by parties involved in any government project. However, they were of the view that the rate of finance charges stated in ICTAD/SBD/02 has to be increased as then the employer will not be hesitant to release the payments without delay to avoid the payment of high finance charges to the contractor. Construction Industry Payment and Adjudication Act, which is expected to be enacted shortly, would help in reducing payment-defaults and increasing dispute resolution (Ameer-Ali, 2006) and the interviewees also highlighted the need to enact this legislation.

\section{CONCLUSIONS AND RECOMMENDATIONS}

When payments get delayed in a project, disputes can arise among the parties involved in the project. Therefore, the factors that can cause delayed payments by the different parties involved within and outside a contract were identified. These factors can cause a significant ripple effect on the parties, particularly when the projects are in developing countries like Sri Lanka. As the work progresses, the timeliness of payments has to be ensured through a regular flow of cash to ensure that all involved parties are financially stable. Thus, it is important to enhance the management of payment delays in government funded construction projects in Sri Lanka. Based on the research findings, the following recommendations can be made to assist the decision makers in the construction sector to prevent delayed payments in government funded construction projects in Sri Lanka:

1. Speedy formulation and enactment of "Construction Industry Security of Payment Act" to safeguard the construction industry and ensure its advancement.

2. Introduction of a payment bond/promissory note, which basically requires a third party, such as a bank or an insurance company, to guarantee the payment in the event of default by the paying party.

3. Establishment of an overall quality assurance system to be used as a check list to prevent the employer from issuing flawed or poorly prepared tender documents.

4. Introduction of milestones or stage payments whereby a pre-agreed sum is paid when the work has reached a certain milestone.

5. Making it a mandatory requirement to set aside a sum of money in an independent escrow account.

6. Making it a right of the contractor to refer to employer's financial status during the bidding stage and to be aware of the actual funding provided the project.

\section{REFERENCES}

Ameer-Ali, N. A. N., 2006. A construction industry payment and adjudication act: Reducing paymentdefault and increasing dispute resolution efficiency in construction. Master Builders, 3, pp.4-14. 
Amoako, K.B., 2011. The effect of delayed payment on cash flow forecasting of Ghanaian road contractors, (Unpublished thesis). Kwame Nkrumah University of Science and Technology.

Ansah, S.K., 2011. Causes and effects of delayed payments by clients on construction projects in Ghana. Journal of Construction Project Management and Innovation, 1(1), pp.27-45.

Andalib, R., Hoseini, A. and Gatmiri, B., 2018. A stochastic model of cash flow forecasting considering delays in owners' payments. Construction Management and Economics, 36(10), pp.1-20.

Artidi, D. and Chotibongs, R., 2005. Issues in Subcontracting Practice; the Placing and Management of Contracts for Building and Civil Engineering Work. Journal of Construction Engineering and Management, 8, pp.866-876.

Badroldin, M.K.A., Hamid, S.A.R., Zakaria, R. and Mohandes, S.R., 2016. Late payment practices in the Malaysian construction industry. Malaysian Journal of Civil Engineering, 28(3), pp.149-162.

Central Bank of Sri Lanka, 2010 - 2016. Central Bank Annual Report, Colombo, Central Bank of Sri Lanka

Danuri, M.S.M., Ishan, Z.M., Mustaffa, N.E., and Jaafar, M.S., 2012. A revisit on the current practice of dispute resolution and ADR in the Malaysian construction industry. Journal of Design and Built Environment, 10(1).

El-adaway, I., Fawzy, S., Burrell, H. and Akroush, N., 2017. Studying payment provisions under national and international standard forms of contracts. Journal of Legal Affairs and Dispute Resolution in Engineering and Construction, 9(2), pp.1-10.

Fellows, R., and Liu, A., 2015. Research Methods for Construction. $4^{\text {th }}$ ed. Sussex: John Wiley and Sons.

Fong, L.C., 2005. Malaysian construction industry - The present dilemmas of the unpaid contractors. Masters Builders, 4, pp.80-82.

Francis, M. and Ramachandra, T., 2014. A Study of payment issues to constructors in the Sri Lankan construction industry. $7^{\text {th }}$ FARU International Research Symposium.

Francis, M., Rotimi, J.O.B. and Ramachandra, T., 2016. Strategies to minimize the effect of delayed payments. Proceedings of the Institution of Civil Engineers.

Francis, M., Ramachandra, T. and Rotimi, J.O.B., 2016. Strategies to minimize the effect of delayed payments. Proceedings of the Institution of Civil Engineers - Management, Procurement and Law, 169(5), pp.199-207.

Hasmori, Muhammad F., Ismail I. and Ilias S., 2012. Issues of late and non-payment among contractors in Malaysia. In: $3^{\text {rd }}$ International Conference on Business and Economic Research (ICBER 2012), 12-13 March 2012, Bandung, Indonesia.

Hughes, W.P, Hillebrandt, P. and Murdoch, J R., 1998. Financial protection in the UK building industry. London: E \& FN Spon.

Hussin, A. A. and Omran, A., 2009. Advance payment: To what extend it "save" the construction works?. Romania, Faculty of Administration and Business, University of Bucharest, Romania.

Zakaria, Z., Ismail, S. and Yusof, A.M., 2012. Cause and impact of dispute and delay the closing of final account in Malaysia construction industry. Journal of Southeast Asian Research, 2012, p.1.

Nasser H., 2013. The Effect of Payment Delay on Construction Projects in Gaza Strip. The Islamic University - Gaza Deanery of Higher Education Engineering Projects Management.

National Construction Association of Sri Lanka, 2009. Report on Payment Delays in Sri Lankan Construction Industry. National Construction Association of Sri Lanka, Battaramulla, Sri Lanka.

Nazir, N.Z., 2006. Late payment problems among contractors in Malaysia. A Masters Dissertation (Construction Management) submitted to the Faculty of Civil Engineering, Universiti Teknologi Malaysia, Skudai, Malaysia.

Pettigrew, R., 2005. The legal and contractual background. In: Payment under construction contracts legislation. Heron Quay: Thomas Telford.

Punch, K., 2014. Introduction to social research: Quantitative and qualitative approaches. $3^{\text {rd }}$ ed. CA: Sage: Thousand Oaks.

Ramachandra, T. and Rotimi, J. O., 2011. The nature of payment problems in the New Zealand construction industry. Australasian Journal of Construction Economics and Building, 11(2), pp.22-33.

Ramachandra, T. and Rotimi, J.O.B., 2015. Causes of Payment Problems in the New Zealand Construction Industry. Construction Economics and Building, 15(1), pp.43-55. 
Ramachandra, T., Rotimi, J. O. and Rameezdeen, R., 2013. Direction of the causal relationship between construction and the national economy of Sri Lanka. Journal of Construction in Developing Countries, 18(2), pp.49-63.

Sambasivan, M., and Soon, Y. W., 2007. Causes and effects of delays in Malaysian construction industry. International Journal of Project Management, 25(5), pp.517-526.

Singh K.S., 2003. Engineering and Construction Contracts Management - Post Commencement Practice. Singapore: Lexis Nexis Business Solutions.

Sirimanna, B., 2012. Construction industry plagued by delayed payments [online]. Sunday Time, Available from: http://www.sundaytimes.lk/120318/BusinessTimes/bt02.html [Accessed 10 September 2018].

Shaban, S.S.A., 2008. Factors affecting the performance of construction projects in the Gaza Strip, Gaza Strip: Islamic University of Gaza.

United Nations Report, 2018. Developing Countries 2018. United Nation.

White, M. D., and Marsh, E.E., 2006. Content Analysis: A Flexible Methodology. Library Trends, 55(1), pp.22-45.

Wiguna, I. P. A. and Scott, S., 2005. Nature of the critical risk factors affecting project performance in Indonesian building contracts. 21 ${ }^{\text {st }}$ Annual ARCOM Conference, 7-9 September 2005, SOAS, University of London. Association of Researchers in Construction Management, 1, pp.225-35.

Ye, K. M. and Rahman, H. A., 2010. Risk of late payment in the Malaysian construction industry. International Journal of Social, Behavioral, Educational, Economic, Business and Industrial Engineering, 4(5), pp.503-511. 